\title{
Participation of various habitat groups in the flora of spring niches in the Ojców National Park (Southern Poland)
}

\section{Anna Sołtys-Lelek ${ }^{1 *}$, Beata Barabasz-Krasny² \& Jacek Różkowski ${ }^{3}$}

\author{
'Ojców National Park, Ojców 9, 32-045 Sułoszowa, Poland \\ ${ }^{2}$ Institute of Biology, Department of Botany, Pedagogical University, Podchorążych 2, 30-084 Kraków, Poland \\ ${ }^{3}$ University of Silesia, Faculty of Earth Sciences, Będzińska 60, 41-200 Sosnowiec, Poland \\ "corresponding author (e-mail: ana_soltys@wp.eu)
}

\begin{abstract}
The paper presents composition of vascular plant species in spring niches in the Ojców National Park (Southern Poland). 111 species of vascular plants, fourteen mosses, two liverworts and one species of ferns were recorded during the first comprehensive study carried out in 2009 and 2010. Plants occurring in these places showed different degrees of association with spring niches. The largest group was represented by accidental krenophytes ( 74 species), while spring plants - obligatory krenophytes, constituted only a small part of the local flora (5 species). Meadow species of the Molinio-Arrhenatheretea class and forest species of the Querco-Fagetea class, penetrating niche areas from the adjacent areas, were the dominating ones. Plants of aquatic and spring communities were scarce, due to the predominance of small type karst springs. The diversity of vegetation was significantly influenced by habitat factors such as availability of light, humidity or the amount of organic matter in the soil.
\end{abstract}

Key words: flora of spring fens, niche sources, various habitat groups of species, Ojców National Park, Poland

\section{Introduction}

Springs are one of the most valuable elements of the karst landscape of the Ojców National Park (ONP). Due to the small area of spring zones in the ONP, the habitats are poorly recognised. No comprehensive studies concerning the floristic structure of spring niches and their character have been carried out. Fragmentary data on spring plants are scattered among works on general flora in the ONP (Michalik 1978), aquatic habitats of Prądnik and Sąspówka streams and some spring fens (Siedlecka-Binder 1967; Medwecka-Kornaś \& Hawro 1993; Sołtys 2005).

Unfortunately, many spring niches in the area have been permanently altered by man, and the degree of those changes is quite varied - from casing, through permanent curbing and deepening. These activities have a huge impact on vascular plants, while common bryophytes easily re-colonize transformed habitats, growing on concrete circles or other constructions.
When natural flora components of spring areas are eliminated by anthropogenic activity, an important role in re-colonization is played by adjacent areas of spring niches which supply propagules of various species.

The main goal of the work was to analyse the floral structure of spring niches in the ONP, determine the share of species of different groups of the habitat in the flora and to indicate the most important factors affecting species variability. The studies will also help to illustrate the degree of transformation of spring niches.

\section{Location and hydrogeological characteristics of the analysed spring niches}

\subsection{Description of the study area}

The Ojców National Park (ONP) is located in southern Poland, $22 \mathrm{~km}$ north-west from Kraków $(\varphi$ $50^{\circ} 12^{\prime} \mathrm{N}, \lambda 19^{\circ} 49^{\prime} \mathrm{E}$ ) (Fig. 1). The ONP is a part of the Kraków-Częstochowa Upland macro-region - the 


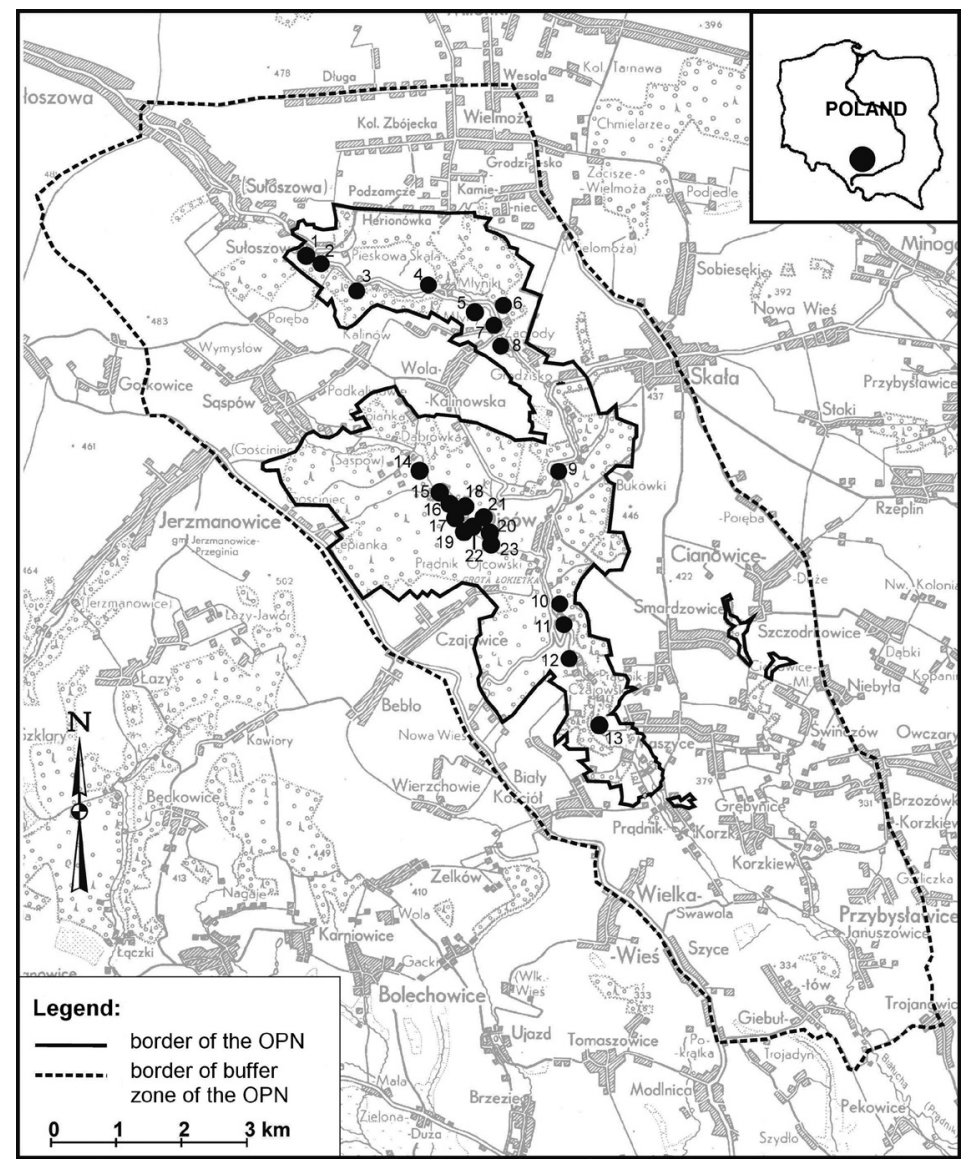

Fig. 1. Localization of the studied spring niches in the Ojców National Park (Southern Poland)

largest karst region in Poland. It covers the area of 2146 ha and together with the buffer zone -6777 ha. The middle part of the Prądnik Valley (12 km long, Fig.
2), the middle and the lower parts of the Saspowska Valley ( $5 \mathrm{~km}$ long) and adjacent areas of the Jurassic plateau are within the park area. The highest parts of

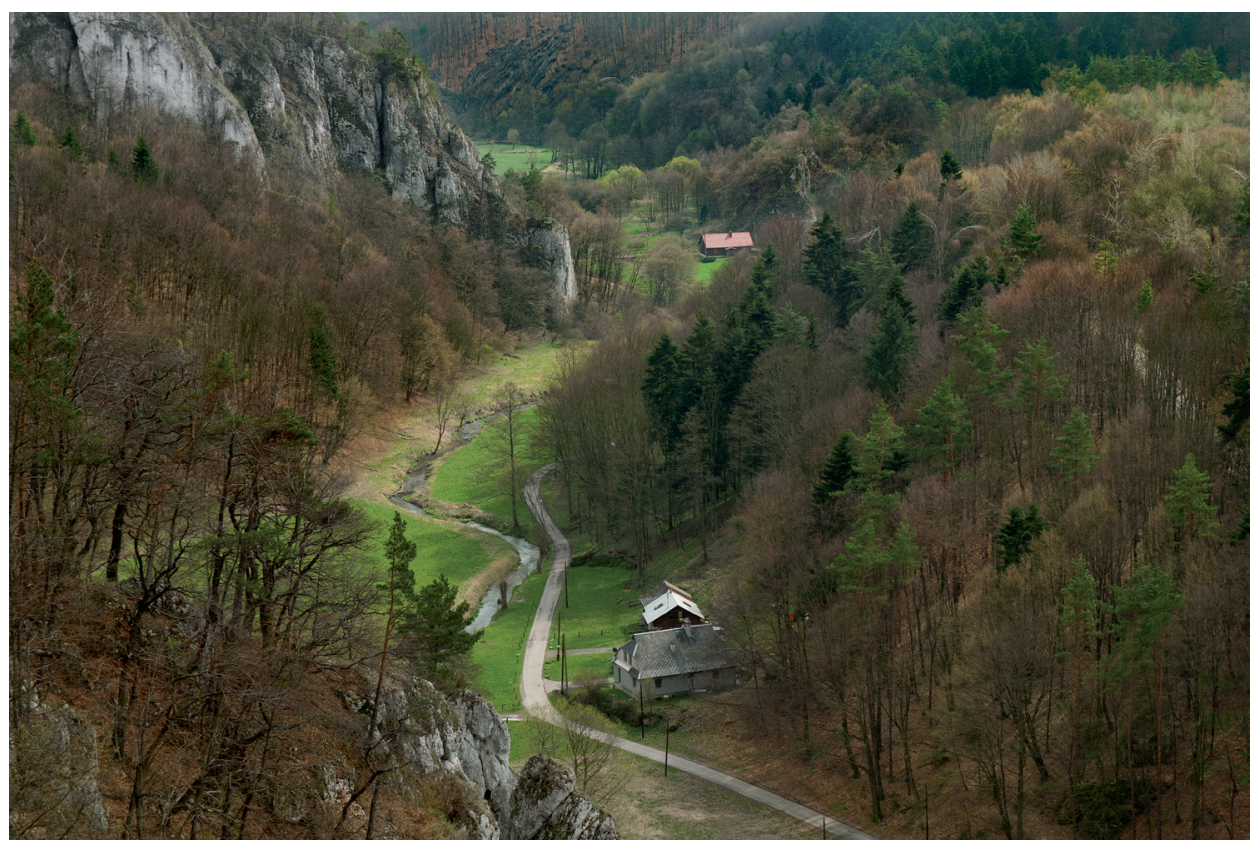

Fig. 2. View of the Prądnik Valley in the Ojców National Park (photograph by R. Cieślik) 


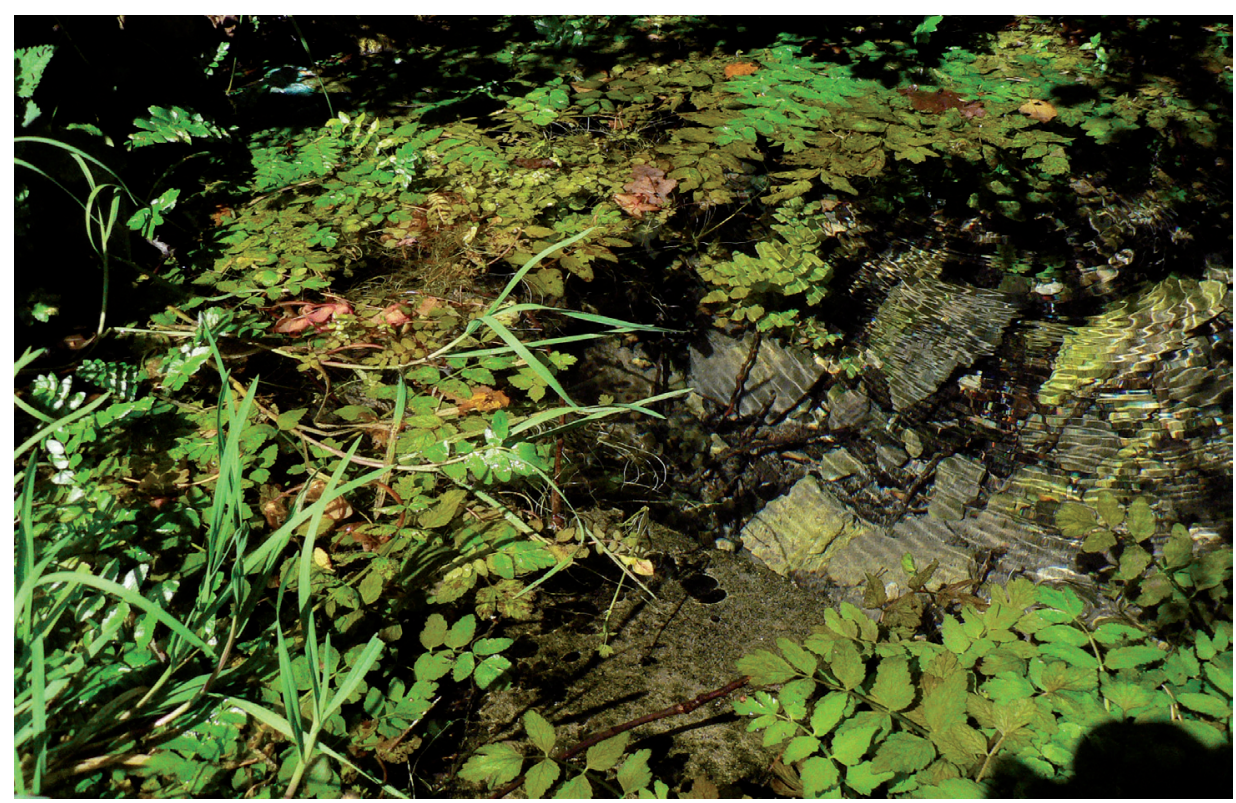

Fig. 3. Outflow of one of the forest springs in the Ojców National Park; the dominant species associated with this spring is Berula erecta (Huds.) Coville (photograph by A. Sołtys-Lelek)

the area reach the altitude of $481 \mathrm{~m}$ a.s.1. and the lowest ones are $-285 \mathrm{~m}$ a.s.1. The geological bed is built of Upper Jurassic limestone whose thickness extends up to 200 m (Partyka \& Klasa 2008).

Strongly varied relief, exposure and denivelation all influence the microclimatic conditions occurring in the ONP which shows characteristic features of mountain climate. Mean precipitation varies from 748 to $773 \mathrm{~mm}$ per year (Brzeźniak \& Partyka 2008). The area of the Park belongs to the zone of moderate warm climate where the average temperature of the year varies from +6 to $+8^{\circ} \mathrm{C}$ and the average annual temperature range is $20.5^{\circ} \mathrm{C}$. Occurrence of thermal inversions conducive to intensive cooling of the bottom of valleys, especially in autumn, is a common phenomenon there. The growing season lasts 203 days in the ONP. The vegetation is characterized by a mosaic arrangement of communities. About $72 \%$ of the Park is covered by forest communities, $22 \%$ by meadows, pastures, xerothermic grasslands and arable lands and $1 \%$ - by water courses (Partyka \& Klasa 2008).

\subsection{Characteristics of the spring niches}

Fissured-karst-porous Upper Jurassic aquifer is the main groundwater basin there. It is an uncovered type basin which is mainly drained by local and intermediate flow systems formed by a varied relief, especially deeply cut valleys of the Prądnik and Sąspówka streams. Underground runoff within the Upper Jurassic aquifer in the Prądnik catchment basin is formed mainly as a result of effective infiltration of precipitation (Różkowski et al. 2001). In 2008-2009, 49 active zones of spring niches, among them 23 zones with a natural outflow, were inventoried in the ONP and its buffer zone (Fig.
3). The springs draining the Upper Jurassic aquifer comprise mainly descending springs (subordinately ascending) as well as under-slope and near-channel ones. The discharge of $80 \%$ of springs is in the range of $0.1-10 \mathrm{dm}^{3} / \mathrm{s}$. The main directions of spring exposures, referring to the tectonics of the rock massive, are as follows: N, NE, SE, SW and NE, only 7 niches have SW and SSW exposures (Fig. 4). Due to the nature of recharge and drainage, there are mainly descending, under-slope and near-channel springs in the area. According to the hydrobiological criterion, horizontal drainage is carried on through karst springs, the ones with spot water outflow. Fens represent karst springs (Sołtys-Lelek et al. 2010).

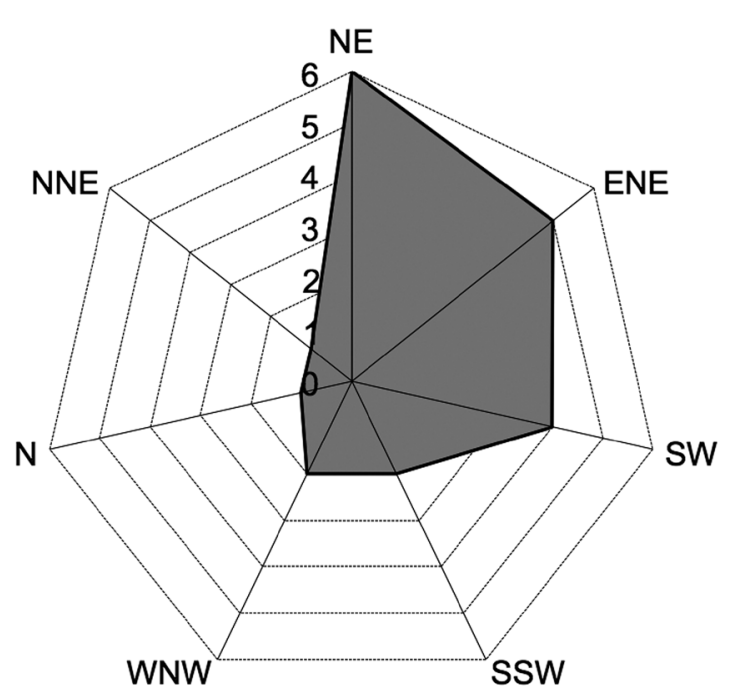

Fig. 4. Exposure of the spring niches investigated in the Ojców National Park 
Waters of the Upper Jurassic level form a shallow flow system in the environment of carbonate rocks. Those are two ionic $\mathrm{HCO}_{3}-\mathrm{Ca}$ waters, with $200-400 \mathrm{mg} / \mathrm{dm}^{3}$ mineralization and dominant carbonate hardness, medium hard $\left(\mathrm{T}_{\mathrm{H}} 190-340 \mathrm{mg} \mathrm{CaCO} / \mathrm{dm}^{3}\right)$. The range of concentrations of macro and secondary components in the waters $\left(\mathrm{mg} / \mathrm{dm}^{3}\right)$ is as follows: $\mathrm{Ca} 70-135 ; \mathrm{Mg} \mathrm{0.1-}$ 11.3; Na 2-14; $\mathrm{K}$ 0.5-13; $\mathrm{HCO}_{3} 205-310 ; \mathrm{SO}_{4}$ 0.3-76; Cl 4-28; $\mathrm{NO}_{3} 5-45 ; \mathrm{PO}_{4} 0.1-3 ; \mathrm{SiO}_{2}$ 6.5-13.5. Calculated values of $\mathrm{SI}_{\text {calc. }}$ saturation (from -0.45 to +0.22 ) prove a state close to the balance of calcite in groundwater, which is characteristic for a scattered flow system, in turn the result of dissolution of carbonate rocks by acidic precipitation. Water temperature is usually $7.610^{\circ} \mathrm{C}$ and it is close to the average temperature of water and air. These are freshwaters (PEW within the range $270-720 \mu \mathrm{S} / \mathrm{cm})$, neutral or slightly alkaline $(\mathrm{pH}$ 7.0-7.5), with oxygen content typical for groundwaters $\left(\mathrm{O}_{2} 6.8-11.0 \mathrm{mg} / \mathrm{dm}^{3}\right)$, representing poorly oxidizing redox conditions (Eh 330-530 mV) (Różkowski 2006).

\section{Material and methods}

It was assumed, for the purpose of the study, that a niche is an outflow spring with the adjacent surroundings of the outflow. 21 spring niches occurring within the ONP boundaries were chosen for the investigation (13 in the Prądnik Valley, 8 in the Sąspowska Valley) and two spring fens in the Sąspowska Valley (Fig. 1). Near-channel and channel springs without spring niches were skipped. Plants occurring within spring niches (in eukrenal and hypokrenal zones) and in slopes of spring niches were recorded in the vegetation seasons of 2009 and 2010 and their quantitative participation was also determined by the Braun-Blanquet scale. During the study, the areas of the niches were measured and percentage of their damage was estimated. Floristic fieldworks were supplemented with archival data from Siedlecka-Binder (1967) and Sołtys (2005).

Syntaxonomic membership of each species was presented on the overall list. It enabled the author to assign most of the plants to the following habitat groups: springs (the Montio-Cardaminetea class according to Wołejko 2000; Górski 2007; Matuszkiewicz 2007; Kliment et al. 2008; Krause \& Wika 2009; Osadowski et al. 2009; Catteau et al. 2010; Parusel et. al. 2012), reeds (the Phragmitetea classes according to Herbich 1981; Matuszkiewicz 2007; Osadowski 2010; Scheuzerio-Caricetea nigrae according to Matuszkiewicz 2007), meadows (the Molinio-Arrhenatheretea class), shrubs (Epilobietea angustifolii, Rhamno-Prunetea classes) forests (Querco-Fagetea, Vaccinio-Piceetea classes) and ruderal (Artemisietea vulgaris, Stellarietea mediae classes) according to Matuszkiewicz 2007. The group "others" included species which showed lack of association to any of the above-mentioned habitat groups.

Division of spring plants according to their habitat requirements was adopted after Kucharski (2007), in a modified version. Obligatory krenophytes (KO) - plants occurring only in spring areas, facultative krenophytes (KF) - plants that find optimum development conditions in the areas of spring, but that may occur also outside them. The group includes hydrophytes and species associated with riparian and coastal habitats of still and flowing surface waters, indifferent krenophytes (KI) - species accepting the conditions of spring zones but having optimum conditions outside them. They are associated with variably moist, moist and wet habitats and flood meadows. They also include indicator species of extremely wet soils, accidental krenophytes (KA) - plants that avoid spring zones, however, sometimes "transferred" there from adjacent habitats.

DCA analysis (Hill \& Gauch 1980) was carried out to investigate which of the selected variables characterising spring zones exerted the most considerable impact on varied floristic content of spring niches. For the purpose of the analysis and considering the immediate vicinity, the niches were divided into the following categories: meadows, tall humid vegetation on alluvial sediments, thicket, forest. Ecological indicator numbers were used to characterise habitats (according to Zarzycki et al. 2002): $\mathrm{L}-$ light, $\mathrm{H}$ - organic matter content, $\mathrm{W}-$ soil moisture, $\mathrm{Tr}$ - trophy, $\mathrm{K}$ - continentality, $\mathrm{R}$ - soil (water) acidity $(\mathrm{pH}), \mathrm{T}-$ temperature. The analysis was carried out on the basis of species contents in particular niches and quantitative participation of species in niches determined by the Braun-Blanquet scale and applying CANOCO programme, version 3.12 (Ter Braak 1991).

The applied nomenclature of vascular plants, ferns and taxonomic membership were adopted from the one used in the study of Mirek et al. (2002), mosses and their taxonomic membership were taken after Ochyra et al. (2003) and liverworts - after Grolle \& Long (2000). The applied syntaxonomic nomenclature was taken after Matuszkiewicz (2007).

\section{Results}

\subsection{Characteristics of the flora of the spring niches}

111 species of vascular plants, fourteen mosses, two liverworts and one species of ferns were found in the spring niches in the Ojców National Park. The following data are presented for each species: the habitat it belongs to, adopted on the basis of phytosociological classification; membership in the plants of spring zones, according to the habitat classification by Kucharski (2007); the numbers of spring niches or spring fens according to the Fig. 1 - given in brackets and citations from literature. Explanations of abbreviations can be 


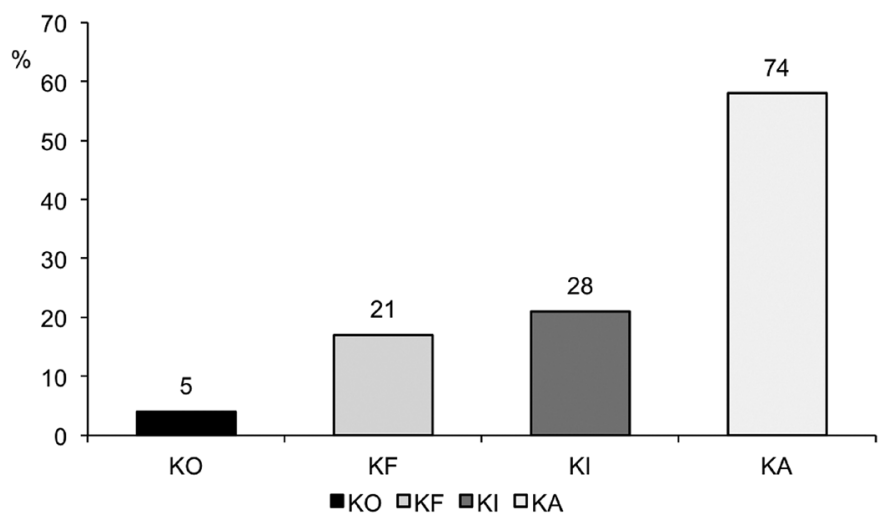

Fig. 5. Comparison of participation of spring-associated plants according to their habitat category Explanations: $\mathrm{KO}$ - krenophytes obligatory, $\mathrm{KF}-\mathrm{k}$. facultative, $\mathrm{KI}-\mathrm{k}$. indifferent, $\mathrm{KA}-\mathrm{k}$. accidental

found in the part describing methodology of the work. List of species is in the Appendix 1.

The following plants occurred most frequently in spring niches in the ONP: Ranunculus repens (15 niches), Cirsium oleraceum (14), Urtica dioica (13), Aegopodium podagraria, Cratoneuron filicinum (12 niches each), Chrysosplenium alternifolium, Lysimachia nummularia, Mentha longifolia, Myosotis palustris (11 niches each), Rumex obtusifolius (10), Brachythecium rivulare, Chaerophyllum hirsutum, Geum urbanum (9 niches each) and Chaerophyllum aromaticum (8). As many as 92 species found there occurred sporadically as they were recorded in 1-3 spring niches only. They represented various syntaxonomic groups. There were also a few protected plants listed under strict protection - Aconitum moldavicum and Epipactis helleborine - and partly protected-Asarum europaeum, Hedera helix and Primula elatior.

Table 1. Comparison of the percentage of spring niches damage in the ONP considering their size and the number of species inhabiting each niche and its neighbourhood

\begin{tabular}{ccrrr}
\hline $\begin{array}{c}\text { Number of niche } \\
\text { in the study area }\end{array}$ & Neighbourhood & $\begin{array}{c}\text { Damage of niche } \\
{[\%]}\end{array}$ & $\begin{array}{c}\text { Area of niche } \\
{\left[\mathrm{m}^{2}\right]}\end{array}$ & Number of species \\
\hline 1 & $\mathrm{~F}$ & 0 & 1.89 & 11 \\
2 & $\mathrm{~F}$ & 100 & 1.00 & 6 \\
3 & $\mathrm{M}$ & 95 & 1.00 & 16 \\
4 & $\mathrm{~T}$ & 20 & 8.00 & 18 \\
5 & $\mathrm{P}-\mathrm{h}$ & 0 & 0.50 & 11 \\
6 & $\mathrm{M}$ & 0 & 5.20 & 23 \\
7 & $\mathrm{M}$ & 90 & 8.10 & 15 \\
8 & $\mathrm{P}-\mathrm{h}$ & 95 & 0.60 & 11 \\
9 & $\mathrm{P}-\mathrm{h}$ & 95 & 1.50 & 12 \\
10 & $\mathrm{P}-\mathrm{h}$ & 95 & 2.00 & 11 \\
11 & $\mathrm{M}$ & 80 & 0.75 & 14 \\
12 & $\mathrm{M}$ & 50 & 2.00 & 24 \\
13 & $\mathrm{~T}$ & 0 & 1.75 & 23 \\
14 & $\mathrm{~F}$ & 0 & 9.00 & 15 \\
15 & $\mathrm{~F}$ & 0 & 12.50 & 19 \\
16 & $\mathrm{~F}$ & 0 & 3.75 & 11 \\
17 & $\mathrm{~F}$ & 5 & 12.00 & 14 \\
18 & $\mathrm{~T}$ & 10 & 4.00 & 14 \\
19 & $\mathrm{~F}$ & 0 & 1.05 & 11 \\
20 & $\mathrm{~T}$ & 0 & 12.00 & 34 \\
21 & $\mathrm{M}$ & 0 & 16.00 & 11 \\
22 & $\mathrm{M}$ & 0 & 25.00 & 28 \\
23 & $\mathrm{M}$ & 0 & 25.00 & 38 \\
\hline
\end{tabular}

Explanations: $\mathrm{F}$ - forest, $\mathrm{M}$ - meadow, $\mathrm{P}-\mathrm{h}$ - tall humid vegetation on alluvial sediments, $\mathrm{T}$ - thicket 
Table 2. Values of the Pearson's correlation (r) between DCA axes and some characteristic features of the studied spring niches in the Ojców National Park

\begin{tabular}{|c|c|c|c|c|}
\hline \multirow{3}{*}{ Characteristics } & \multicolumn{4}{|c|}{ Correlation values } \\
\hline & \multicolumn{2}{|c|}{ Quality } & \multicolumn{2}{|c|}{ Quantity } \\
\hline & Axis I & Axis II & Axis I & Axis II \\
\hline \multicolumn{5}{|l|}{ Zarzycki indicators: } \\
\hline $\mathrm{L}$ - light value & 0.81 & -0.03 & 0.87 & 0.02 \\
\hline $\mathrm{H}$ - organic matter content value & 0.76 & 0.21 & 0.73 & -0.21 \\
\hline $\mathrm{W}$ - soil moisture value & 0.79 & 0.01 & 0.68 & -0.19 \\
\hline $\mathrm{Tr}$ - trophy value & 0.12 & -0.26 & 0.13 & 0.17 \\
\hline $\mathrm{K}$ - continentality value & -0.10 & -0.34 & -0.11 & -0.19 \\
\hline $\mathrm{R}$ - soil (water) acidity $(\mathrm{pH})$ value & -0.24 & -0.14 & -0.12 & 0.03 \\
\hline $\mathrm{T}$ - temperature value & -0.21 & 0.24 & -0.16 & -0.07 \\
\hline $\mathrm{KO}$ - krenophytes obligatory & 0.03 & 0.19 & 0.26 & 0.06 \\
\hline $\mathrm{KF}$ - krenophytes facultative & 0.61 & 0.28 & 0.55 & -0.13 \\
\hline KI - krenophytes indifferent & 0.52 & -0.05 & 0.65 & 0.05 \\
\hline KA - krenophytes accidental & 0.04 & -0.05 & 0.20 & 0.06 \\
\hline Exposition & 0.05 & -0.01 & 0.08 & -0.14 \\
\hline Damage of niche & 0.24 & -0.26 & 0.42 & -0.07 \\
\hline Area of niche & 0.03 & 0.43 & 0.02 & 0.36 \\
\hline Number of species in a niche & 0.36 & 0.03 & 0.50 & 0.04 \\
\hline
\end{tabular}

The largest habitat group in the niches was represented by meadow species of the Molino-Arrhenatheretea class (37 species); within the group - 17 species of the Molinietalia caerulae order were associated with variable moist, moist or wet meadows. The second largest group comprised 26 species of forest plants of the Querco-Fagetea class. Among them, special attention should be paid to the species associated with riparian marshes - Alno-Ulmion. The flora of communities of the Scheuchzerio-Caricetea nigrae class in poor fens and fens and of the Phragmitetea class in reed beds comprised 11 species altogether. There were also a few representatives of the Montio-Cardaminetea class which included plants occurring in specific conditions of seepage spring areas. Six species represented bryophytes: Brachythecium rivulare, Conocephalum conicum, Cratoneuron filicinum, Pellia epiphylla, Plagiothecium laetum, Rhizomnium punctatum and three - vascular plants: Cardamine amara, Chrysosplenium alternifolium, Impatiens noli-tangere. Investigation of the seepage spring areas proved also the occurrence of nitrophilous species belonging to the Artemisietea vulgaris, Stellarietea mediae and Epilobietea angustifolii class - 19 species altogether (Appendix 1).

Among plants of spring fens with different habitat requirements, obligatory krenophytes comprised only

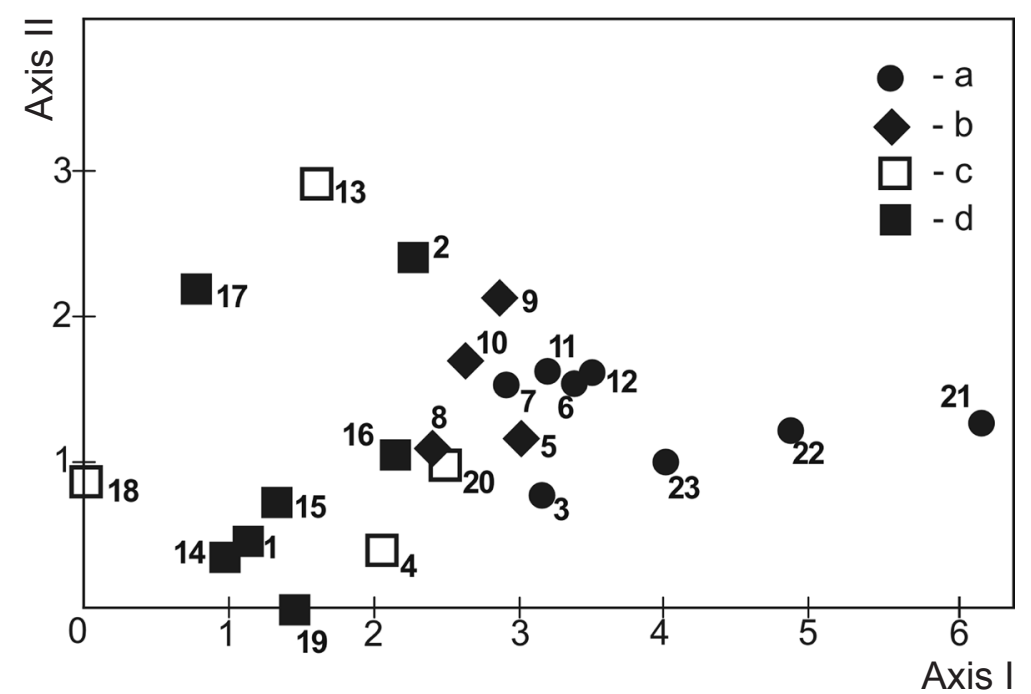

Fig. 6. Ordination of spring niches in the Ojców National Park along the first two DCA axes. based on species composition; division of spring niches considering their immediate vicinity

Explanations: $\mathrm{a}$ - meadow, $\mathrm{b}$ - tall humid vegetation on alluvial sediments, $\mathrm{c}$ - thicket, $\mathrm{d}$ - forest 
$4 \%$ of them (one moss, one liverwort and three vascular plants), facultative krenophytes comprised 17\% (four mosses and 17 vascular plants), indifferent krenophytes comprised $21 \%$ of them (three mosses, one liverwort and 24 vascular plants) and accidental krenophytes comprised 58\% (six mosses - mostly forest ones, one species of ferns and 67 vascular plants, Fig. 5).

Small niches, with areas smaller than $10 \mathrm{~m}^{2}$ (17 of 23 niches) were found to occur most commonly in the ONP (Table 1). Almost half of the niches - 11 showed signs of damage and up to 8 revealed damage of the surface exceeding $50 \%$. The niches richest in species occurred near meadows (15-38 species) and shrubs (1434 species), the abundance was the result of transfer of species associated with the habitats.

DCA analysis carried out to verify which of the selected variables characterizing spring fens exerted the greatest impact on the diversity of their floristic composition showed that the following factors played important roles: availability of light, organic matter content, moisture content which resulted in the occurrence of facultative and indifferent krenophytes, and the number of species in the niche (Table 2). The niche area and the degree of its damage showed lower correlation.

Graphic presentation of the relationships based on species contents showed ordering of the niches along the DCA axis I - from forest-shrubs with a small amount of facultative and indifferent krenophytes, with lower light availability, organic matter content and moisture (left side of the graph) to meadow niches with a large share of the above-mentioned two types of krenophytes, with higher availability of light, moisture and organic matter content (right side of the graph). The surface of niches was the only factor weakly correlated with the axis II (Fig. 6, Table 2).

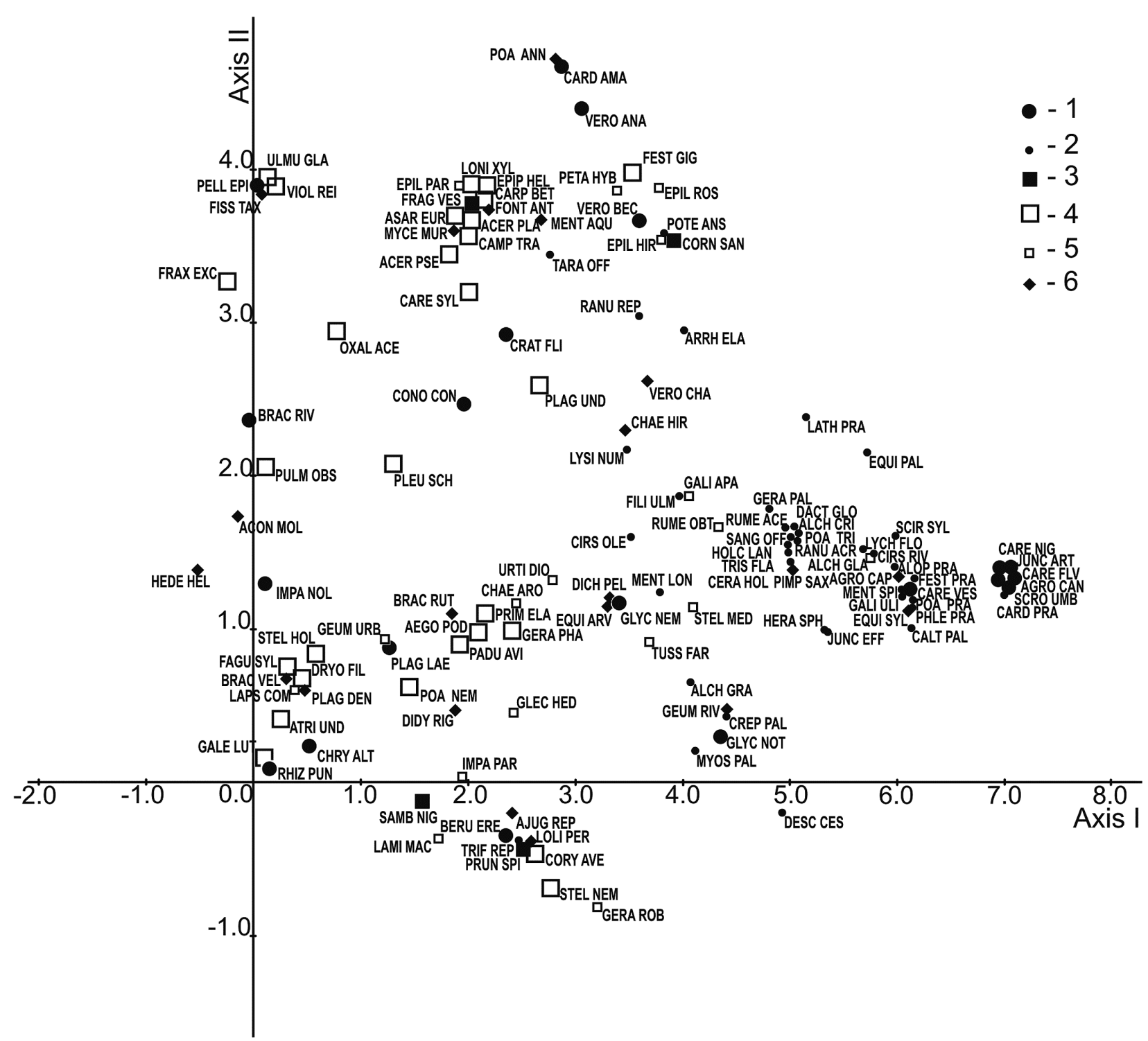

Fig. 7. Ordination of species of spring niches in the Ojców National Park along the first two DCA axes, based on their quantitative participation Explanations: 1 - Classes Montio-Cardaminetea, Scheuzerio-Caricetea nigrae, Phragmitetea, 2 - Orders Trifolio fragiferae-Agrostietalia stoloniferae, Molinietalia coeruleae, Arrhenatheretalia and Class Molinio-Arrhenatheretea, 3 - Classes Epilobietea angustifolii and Rhamno-Prunetea, 4 - Alliance AlnoUlmion, Classes Querco-Fagetea and Vaccinio-Piceetea, 5 - Classes Artemisietea vulgaris and Stellarietea mediae, 6 - other habitats (with different humidity) 
Table 3. Participation of different habitat groups of species in the flora of spring niches in the Ojców National Park

\begin{tabular}{lcc}
\hline \multicolumn{1}{c}{ Habitat groups of species } & $\begin{array}{c}\text { Number } \\
\text { of species }\end{array}$ & $\begin{array}{c}\text { Participation in the } \\
\text { flora of the niches [\%] }\end{array}$ \\
\hline Montio-Cardaminetea (spring fens and places, where arrears snow) & 9 & 7 \\
Scheuzerio-Caricetea nigrae (poor fens and fens) & 4 & 3 \\
Phragmitetea (rushes, reeds) & 7 & 5 \\
Trifolio fragiferae-Agrostietalia stoloniferae (floodplain grasslands) & 3 & 2 \\
Molinietalia coeruleae (meadows constantly and periodically wet) & 17 & 13 \\
Arrhenatheretalia (fresh meadows and pastures) & 7 & 5 \\
Molinio-Arrhenatheretea (fresh and moist meadows - joint species) & 10 & 8 \\
Epilobietea angustifolii (nitrophilous clippings and ruderal places) & 2 & 2 \\
Rhamno-Prunetea (thermophilous thickets) & 2 & 2 \\
Alno-Ulmion (moist riparian forests) & 5 & 4 \\
Querco-Fagetea (deciduous forests - different humidity) & 21 & 17 \\
Vaccinio-Piceetea (coniferous forests and woods - different humidity) & 2 & 2 \\
Artemisietea vulgaris (moist, ruderal and nitrophilous places) & 14 & 11 \\
Stellarietea mediae (weeds of cultivated fields and ruderal places) & 3 & 2 \\
Other habitats (different humidity) & 22 & 17 \\
Total & 128 & 100 \\
\hline
\end{tabular}

Ordering of species based on their quantitative share in niches along the DCA axis I showed that the existing plants could be grouped according to the habitat gradients - from the most shade-loving plants (of the Querco-Fagetea, Vaccinio-Piceetea class) medium wet, with a lower content of organic matter, growing in niches poor in species (left side of the graph) to photophilous ones (of the Scheuzerio-Caricetea nigrae, Phragmitetea, Molinio-Arrhenatheretea class), wet, which liked relatively fertile soil, belonging to facultative and indifferent krenophytes, associated with niches with a large number of species (right side of the graph). In this case, the DCA axis II did not show any significant correlation (Fig. 7, Table 2).

\section{Discussion}

Springs are such ecosystems where groundwaters reach the surface of the ground or they get close to the surface, on land - atmosphere or land - water boundaries. Geomorphological conditions of springs enable functioning of many biological micro-environments and a wide range of plant and animal species. The impact on the occurrence and development of seepage spring areas and their rich biodiversity is a combination of the following factors: geological (ground lithology), hydrogeological (water circulation conditions, yield of discharges, water chemistry), geomorphological (types of springs, processes of erosion) and biocenotic (fauna and flora) (Szulc 1983; Allan 1998; Pazdur et al. 2002; Pentecost 2005; Osadowski 2010). A significant role is played by anthropogenic factors, taking into account development of the drainage area of springs and the degree of its urbanization. In the opinion of many ecologists, drainage areas of springs are so called "ecological islands" having favourable conditions for the development of specialized organisms (Cantonati \& Lange-Bertalot 2006; Osadowski 2010). They are also a refugium for protected and endangered species, including the ones of mountain and foothill character (Kucharski \& Filipiak 1999; Szymczyk \& Rahmonov 2010). Due to their high susceptibility to changes in environmental ecosystems, the areas were considered to be endangered not only in Poland but also in the entire continent (Kurowski et al. 2008).

The seepage spring areas occupy only approximately 0.015 hectares in the ONP. 111 species of vascular plants, representing $11 \%$ of the flora of the Park were found within that small area. Siedlecka-Binder (1967) had reported earlier only 12 vascular plants and 2 species of mosses in spring areas and 32 species of vascular plants, 6 bryophytes and 1 liverwort species in watercourses. Typical vegetation of seepage spring areas of the Montio-Cardaminetea class represents a small percentage - just $7 \%$ of the niche flora, despite natural conditions caused by specific water chemistry which favours its development (Różkowski 2006). Currently identified species of vascular plants belong up to 11 syntaxonomic classes, among them the most numerous are: Molino-Arrhenatheretea and Querco-Fagetea (Table 3). Similar proportions in the composition of vegetation in spring areas were earlier observed during the research of those types of habitats (Kucharski \& Filipiak 1999; Kucharski 2007). Occurrence of representatives of the above-mentioned two classes was closely connected with the vicinity of springs - mostly 
hay meadows - Arrenatheretum elatioris, deciduous forests Tilio-Carpinetum and riparian forests with Alno-Ulmion. Hence, it can be stated that the immediate vicinity of spring niches was one of the most important factors influencing the flora of spring fens in the ONP. It mainly resulted from the fact that most of the spring fens were small karst springs easily penetrated by species from the neighbouring areas. It often led to transfer of plants atypical for the habitat (accidental krenophytes - Fig. 5), sometimes even ruderal, which were additionally favoured by a considerable degree of niche damage (Table 1). Ruderalisation phenomena of spring fen vegetation were observed, for example, by Czarnecka (2009) in some spring fens located at the edge zone of Roztocze (Eastern Poland). However, they mostly concerned spring fens covering large areas, where strong anthropopressure occurred.

The degree of damage of spring fen niches mainly refers to various forms of their reconstruction or outflow control regulated by mounting pipes or barriers raising water, placing open or closed concrete rings. Totally destroyed niches are completely reconstructed by covering them by a construction in the form of a concrete house or something like a well, where concrete casing covers the walls of the well and the outflow is covered as well - the so-called covered casing. Niches with no visible damages are natural ones, i.e. the ones with spring outflows with no visible signs of anthropogenic impact. In the period of 2008-2009, the ONP made an inventory of 32 active spring fen niches, including 3 secondary outflow intakes (Sołtys-Lelek et al. 2010). Only 16 springs of those had natural, nontransformed outflows. More than half of the spring fens chosen for the current studies had niches damaged to various degrees. Apart from that, most of them covered the area smaller than $3 \mathrm{~m}^{2}$ and only four of them were larger than $10 \mathrm{~m}^{2}\left(12-16 \mathrm{~m}^{2}\right)$; the largest were seepage springs covering the area of approximately $25 \mathrm{~m}^{2}$ (Table 1). Small size of niches caused that the degree of damage indirectly affected species content in the vegetation occurring there. Perhaps the degree of damage entailed occurrence of a small amount of typical spring species of the Montio-Cardaminetea class, which were sensitive to anthropogenic impact on their habitat and a relatively large share of ruderal species of Stellarietea and Artemisietea classes (Table 3). Despite the occurrence of a favourable habitat of carbonate rocks, occurrence of limestone spring fen communities Cratoneurion commutati was not corroborated within the area of the ONP. Although, Cratoneuron filicinum was confirmed in nearly half of the spring niches, other typical species for that relation were not found in the vicinity of springs. On the other hand, ruderal species occurred in the niches regardless of the neighbourhood, because they showed considerable tolerance to habitat disturbance and disruption of the ecosystem natural balance of (Fig. 7, Table 2).

Habitat conditions constituted another very important factor influencing the floristic composition of spring fens in the ONP. As it was shown by the investigations, the most important environmental factors included: availability of light, humidity and the content of organic matter in the soil (Table 2, Figs. 6-7). Light indicator was the factor that had the biggest impact on the diversity of floristic composition in the niches. It exhibited the highest value of the correlation coefficient with the DCA axis I. Species living in moderate light and partial shadow $(\mathrm{L}=3-4)$ were associated with open habitats such as meadows and reed habitats (Figs. 6-7 - the right side of the graph). They constituted the largest floristic group of the investigated niches. The second largest group in the niches comprised shade-loving species growing in places - from deep shadow through moderate shade to half-shade $(\mathrm{L}=1-2-3)$. The species were associated with the forest-shrub niches (Figs. 6-7 - the left side of the graph). Other important habitat factors in case of spring fen plants also included moisture and organic matter content in the soil, as mentioned above. Hygrophytes and mesophytes comprised majority of species growing in spring niches. Especially, the first group was very sensitive to fluctuations in soil moisture. They tolerated fresh soil, but they grew best on damp and wet soils $(\mathrm{W}=3-4-5)$. In terms of organic matter content, they tolerated mineral-humus and organogenic soils $(\mathrm{H}=2-3)$ (Zarzycki et al. 2002).

Generally, the floristic composition of spring niches in the ONP was significantly altered due to small area of the niches and strong anthropopressure. However, there are still habitats in that area which shelter rare species of moisture-loving plants and animals. Therefore, they should be protected against further devastation by man, mostly occurring in meadow niches, which are often located within the limits of villages and easily accessible to the local population. An attempt should also be made, especially within the area of the Ojców National Park, to re-naturalise the altered spring areas. Work of this kind should include monitoring of botany, entomology and hydrology. First, the re-naturalization must cover the springs where fragmentary spring fens are still preserved and there is a chance to rebuild their typical flora and fauna. Such springs as the one "by the car park" in Pieskowa Skała (spring No 2) or "near the SOP station" in Ojców (spring No 12) can serve as good examples (Fig. 1).

\section{Conclusions}

1. 128 species, including 111 species of vascular plants, 14 mosses and two liverworts and one species of ferns were found in the area of 21 spring niches and two spring fens. 
2. Accidental species - accidental krenophytes (KA), avoiding cold habitats and occasionally migrating from adjacent communities are the largest group (57\% of the flora).

3. Meadow and forest plants comprise the largest group of spring habitats in the ONP. On the other hand, water community and spring fen plants (Montio-Cardaminetea class) are rare, due to the dominance of small karst springs. The species composition was formed there mostly by the impact of the immediate neighbourhood of spring niches.

4. Habitat factors such as availability of light, organic matter content, moisture content have significant influence on floristic diversity. The niche area and the degree of its damage show lower correlation.
5. Anthropogenic factors connected with transformation of spring fens that facilitate penetration of species from the immediate neighbourhood, quite often of ruderal character, have indirect influence on the floristic composition of these niches.

Acknowledgements. We would like to thank Barbara Fojcik $\mathrm{Ph} . \mathrm{D}$. from the University of Silesia in Katowice (Poland) for identification of bryophytes and consultation on this group of plants. We would also like to thank Prof. Leszek Kucharski from the University in Łódź (Poland) for his help in determining division of spring plants, according to their habitat requirements.

\section{References}

Allan J. D. 1998. Ekologia wód płynących. 452 pp. Wyd. Nauk. PWN, Warszawa.

Brzeźniak E. \& Partyka J. 2008. Warunki klimatyczne Ojcowskiego Parku Narodowego. In: A. KLASA \& J. PARTYKa (eds.). Monografia Ojcowskiego Parku Narodowego. Przyroda, pp. 121-136. Wyd. OPN, Ojców.

Cantonati M. \& Lange-Bertalot H. 2006. Achnanthidium dolomiticum sp. nov. (Bacillariophyta) from oligotrophic mountain springs and lakes fed by dolomite aquifers (Note). J. Phycol. 42(6): 1184-1188. DOI: 10.1111/j.1529-8817.2006.00281.x

Czarnecka B. 2009. Źródła strefy krawędziowej Roztocza: zróżnicowanie szaty roślinnej a stan środowiska. Infrastruktura i Ekologia Terenów Wiejskich 6: 27-43.

Catteau E., Duhamel F., Cornier T., Farvacques C., Mora F., Delplanque S., Henry E., Nicolazo C. \& Valet J. M. 2010. Guide des végétations forestières et préforestières de la région Nord-Pas de Calais. 526 pp. Centre régional de phytosociologie agréé Conservatoire botanique national de Bailleul, Bailleul.

GóRSKI P. 2007. Liverworts of the nature reserves in Wielkopolska. 4. "Dolina Kamionki". Roczn. Akad. Roln. w Poznaniu 386, Botanika - Steciana 11: 73-76.

Grolle R. \& Long D.G. 2000. Hepatics of Europe including the Azores: an annotated list of species, with synonyms from the recent literature. J. Bryol. 12: 403-459.

HeRBich J. 1981. Glycerietum nemoralis-plicatae Kopecký 1972 - a new plant association in Poland. Fragm. Flor. Geobot. 27(1-2): 165-170.

Hill M. \& Gauch H. G. 1980. Detrended Correspondence Analysis: an improved ordination technique. Vegetatio 42: 47-58.

Hill M. O., Preston C. D., Bosanquet S. D. S. \& Roy D. B. 2007. Bryoatt. Attributes of British and Irish mosses, liverworts and hornworts. NERC Centre for Ecology and Hydrology and Countryside Council for Wales. 88 pp. The Saxon Print Group, Norwich.
Kliment J., Kochjarová J., Hrivnák R. \& Šoltés R. 2008. Spring communities of the Vel'ká Fatra Mts (Western Carpathians) and their relationship to central European spring vegetation. Pol. Bot. J. 53: 29-55.

KRAUSE R., WIKa S. 2009. Zróżnicowanie roślinności źródliskowej z klasy Montio-Cardaminetea w zachodniej części Beskidów Zachodnich. Materiały Opracowania Centrum Dziedzictwa Przyrody Górnego Śląska w Katowicach 10: 91 pp.

KUChARSKI L. \& FilipiaK E. 1999. Szata roślinna obszarów źródliskowych środkowej Polski i jej ochrona. In: E. Biesiadko \& S. Czachorowski (eds.). Źródła Polski. Stań badań, monitoring i ochrona, pp. 87-94, Wyd. WSP, Olsztyn.

KUCHARSKI L. 2007. Flora źródlisk - skład i gatunki wskaźnikowe. In: P. JokIEL, P. Moniewski \& M. ZiUŁKIEWICZ (eds.). Źródła Polski. Wybrane problemy krenologiczne, pp. 62-68, Wyd. Wydziału Nauk Geograficznych Uniwersytetu Łódzkiego, Łódź.

Kurowski J. K., KiedRZyŃski M., ŁucZAK M. \& GielNiaK P. 2008. Śródleśne źródliska - problemy ochrony i waloryzacji na przykładzie regionu łódzkiego. Studia i Materiały Centrum Edukacji Przyrodniczo-Leśnej 10, 2(18): 118-135.

Matuszkiewicz W. 2007. Przewodnik do oznaczania zbiorowisk roślinnych Polski. In: J. B. FALIŃSKi (ed.). Vademecum Geobotanicum 3, 537 pp. Wyd. Nauk. PWN, Warszawa.

Medwecka-Kornaś A. \& Hawro R. 1993. Wpływ bobrów na roślinność potoku Sąspówka w Ojcowskim Parku Narodowym. In: A. Biderman \& B. Wiśniowski (eds.). Utrzymanie i restytucja ginących gatunków roślin i zwierząt w parkach narodowych i rezerwatach przyrody, pp. 89-100. Prace Muzeum Szafera, Ojców.

Michalik S. 1978. Rośliny naczyniowe Ojcowskiego Parku Narodowego. Studia Nat. Ser. A. 16: 1-138. 
Mirek Z., Piękoś-Mirkowa H., Zając A. \& Zając M. 2002. Flowering plants and pteridophytes of Poland. A checklist. In: Z. MiReK (ed.). Biodiversity of Poland, 1, 442 pp. W. Szafer Institute of Botany, Polish Academy of Sciences, Kraków.

Ochyra R., Żarnowiec J. \& Bednarek-Ochyra H. 2003. Census Catalogue of Polish Mosses. In: Z. Mirek (ed.). Biodiversity of Poland, 3, $372 \mathrm{pp}$. Polish Academy of Sciences, Institute of Botany, Kraków.

Osadowski Z., Mazurek M. \& Dobrowolski R. 2009. Structure and development conditions of spring mires in the Parsęta basin (Western Pomerania). Chapter VI. In: Contemporary Problems of Management and Environmental Protection. Wetlands - Their Functions and Protection 2: 107-124.

OsADOWski Z. 2010. Wpływ uwarunkowań hydrologicznych i hydrochemicznych na zróżnicowanie szaty roślinnej źródlisk w krajobrazie młodoglacjalnym Pomorza. 177 pp. Bogucki Wyd. Nauk., Poznań.

Partyka J. \& Klasa A. 2008. Ojcowski Park Narodowy wiadomości ogólne. In: A. Klasa \& J. Partyka (eds.). Monografia Ojcowskiego Parku Narodowego - Przyroda, pp. 19-28, Wyd. OPN, Ojców.

Parusel J. B., Cabala S., Hereźniak J. \& Wika S. (eds.) 2012. Czerwona lista zbiorowisk roślinnych województwa śląskiego. Raporty Opinie 6(3): 7-60.

Pazdur, A., Dobrowolski R., Mohanti M., Durakiewicz T., Piotrowska N. \& Das S. 2002. Radiocarbon time scale for deposition of Holocene calcareous tufa from Poland and India (Orissa). Geochronometria 21: 85-96.

Pentecost A. 2005. Hot springs, thermal springs and warm springs. What's the difference? Geology Today 21: 222-224. DOI: 10.1111/j.1365-2451.2005.00536.x

Różkowski J., KowalczyK A., Rubin K. \& Wróbel J. 2001. Odnawialność wód szczelinowo-krasowych poziomu górnojurajskiego w obszarze Wyżyny Krakowskiej - na podstawie modelowania matematycznego. In: T. BOCHEŃSKa \& S. STAŚKo (eds.). Współczesne problemy hydrogeologii, 10, pp. 245-252, Wyd. Sudety, Wrocław-Krzyżowa.
RóżKOwSKi J. 2006. Wody podziemne utworów węglanowych południowej części Jury Krakowsko-Częstochowskiej i problemy ich ochrony. Prace Nauk. UŚ 2430. 263 pp. Wyd. Uniwersytetu Śląskiego, Katowice.

SIEDLECKA-BINDER Z. 1967. Roślinność wodna w potokach Ojcowskiego Parku Narodowego. Ochr. Przyr. 32: 171-203.

SoŁTYs A. 2005. Nowe gatunki roślin naczyniowych we florze Ojcowskiego Parku Narodowego. Chrońmy Przyr. Ojcz. 61(4): 18-23.

SoŁtys-Lelek A., Różkowski J. \& Lelek K. 2010. Wpływ antropopresji na środowisko biotyczne i abiotyczne stref źródliskowych na obszarze Ojcowskiego Parku Narodowego i jego otuliny. Prądnik. Prace Muz. Szafera 20: 377-396.

Szulc J. 1983. Geneza i klasyfikacja wapiennych osadów martwicowych. Przegl. Geolog. 31(4): 231-237.

SZYMCZYK A. \& RAHMONOV O. 2010. Szata roślinna antropogenicznych cieków i stref wypływów wód w piaskowni „Siemonia”. Kształtowanie środowiska geograficznego i ochrona przyrody na obszarach uprzemysłowionych i zurbanizowanych 42: 80-87.

TER BRAAK C. J. F. 1991. CANOCO - a FORTRAN program for canonical community ordination by (partial) (detrended) (canonical) correspondence analysis, principal components analysis and redundancy analysis. New York: 3.12. Microcomputer Power.

WoŁejko L. 2000. Roślinność leśna i zaroślowa (klasy Alnetea glutinosae i Querco-Fagetea) kompleksów źródliskowych Polski północno-zachodniej. Folia Univ. Agric. Stetin. 213. Agricultura 85: 297-320.

ZAJĄC M. \& ZAJĄC A. 2009. The geographical elements of native flora of Poland. $94 \mathrm{pp}$. Edited by Laboratory of Computer Chorology, Institute of Botany, Jagiellonian University, Kraków.

Zarzycki K., TrZcińSKa-Tacik H., RóżaŃSKi W., Szeląg Z., WoŁEK J. \& KorZENIAK U. 2002. Ecological indicator values of vascular plants of Poland. In: Z. MireK (ed.). Biodiversity of Poland, 2, 183 pp. W. Szafer Institute of Botany, Polish Academy of Sciences, Kraków. 
Appendix 1. List of plant species recorded in the spring niches of the Ojców National Park

\begin{tabular}{|c|c|c|c|c|}
\hline Name of species & $\begin{array}{l}\text { Category of } \\
\text { spring plants }\end{array}$ & $\begin{array}{c}\text { Number of spring niche } \\
\text { in ONP }\end{array}$ & $\begin{array}{l}\text { Geographical } \\
\text { element }\end{array}$ & Family \\
\hline \multicolumn{5}{|c|}{ Spring fens and places, where snow lies (Class Montio-Cardaminetea Br.-Bl. et R.Tx. 1943) } \\
\hline Pellia epiphylla (L.) Corda. & $\mathrm{KO}$ & 17 & $\mathrm{CB}$ & Pelliaceae \\
\hline Brachythecium rivulare Schimp. & $\mathrm{KF}$ & $\begin{array}{l}1,2,6,9,11,14,15,16, \\
17\end{array}$ & $\mathrm{CB}$ & Brachytheciaceae \\
\hline Conocephalum conicum (L.) Dumort & KI & $12,13,15,17,19,20$ & $\mathrm{E}$ & Conocephalaceae \\
\hline Cratoneuron filicinum (Hedw.) Spruce & $\mathrm{KO}$ & $\begin{array}{l}2,3,5,9,10,11,12,13 \\
14,15,18,20\end{array}$ & $\mathrm{CB}$ & Cratoneuraceae \\
\hline Plagiothecium laetum Schimp. & KA & 18,20 & $\mathrm{CB}$ & Plagiotheciaceae \\
\hline Rhizomnium punctatum (Hedw.) T. J. Kop. & $\mathrm{KF}$ & 14 & $\mathrm{CB}$ & Cinclidiaceae \\
\hline Cardamine amara $\mathrm{L}$. & $\mathrm{KF}$ & 9 & $\mathrm{CE}$ & Brassicaceae \\
\hline Chrysosplenium alternifolium $\mathrm{L}$. & $\mathrm{KF}$ & $\begin{array}{l}1,5,7,8,14,15,16,17 \\
18,19,20\end{array}$ & ES & Saxifragaceae \\
\hline Impatiens noli-tangere L. & $\mathrm{KI}$ & 1,20 & $\mathrm{CB}(\mathrm{d})$ & Balsaminaceae \\
\hline
\end{tabular}

\begin{tabular}{|c|c|c|c|c|}
\hline \multicolumn{5}{|c|}{ Poor fens and fens (Class Scheuzerio-Caricetea nigrae (Nordh. 1937) R.Tx. 1937) } \\
\hline Agrostis canina L. & KI & 21 & sa-ES & Poaceae \\
\hline Carex flava $\mathrm{L}$. & $\mathrm{KF}$ & 21 & CB: c-b-o & Cyperaceae \\
\hline Carex nigra Reichard & $\mathrm{KI}$ & 21 & $\mathrm{CB}(\mathrm{d})$ & Cyperaceae \\
\hline Juncus articulatus L. emend. K. Richt. & $\mathrm{KF}$ & 21 & $\mathrm{CB}$ & Juncaceae \\
\hline \multicolumn{5}{|c|}{ Rushes, reeds (Class Phragmitetea R.Tx. et Prsg 1942) } \\
\hline Berula erecta (Huds.) Coville & $\mathrm{KO}$ & 4,19 & $\mathrm{CB}(\mathrm{d})$ & Brassicaceae \\
\hline Carex versicaria $\mathrm{L}$. & $\mathrm{KF}$ & 22 & CB: c-b-a & Cyperaceae \\
\hline $\begin{array}{l}\text { Glyceria nemoralis (R. Uechtr.) R. Uechtr.\& } \\
\text { Körn. }\end{array}$ & $\mathrm{KF}$ & 20 & CE-PAN-PONT & Poaceae \\
\hline Glyceria notata Chevall. & $\mathrm{KO}$ & $2,4,5,6,13,20,22,23$ & sa-CE-M-IR(m) & Poaceae \\
\hline $\begin{array}{l}\text { Scrophularia umbrosa Dumort. - species } \\
\text { reported in the ' } 60 \text { s of the 20th century } \\
\text { (Siedlecka-Binder 1967) }\end{array}$ & $\mathrm{KF}$ & 21 & ES(d)-IR & Scrophulariaceae \\
\hline Veronica anagallis-aqatica $\mathrm{L}$. & $\mathrm{KF}$ & $6,9,11$ & sa-ES-M-IR & Scrophulariaceae \\
\hline Veronica beccabunga $\mathrm{L}$. & $\mathrm{KO}$ & $6,9,10,12,20,23$ & $\begin{array}{l}\text { sa-ES(w)-M(n)- } \\
\text { IR }\end{array}$ & Scrophulariaceae \\
\hline
\end{tabular}

\begin{tabular}{lcccc}
\hline \multicolumn{5}{c}{ Floodplain grasslands (Order Trifolio fragiferae-Agrostietalia stoloniferae R.Tx. 1970) } \\
\hline Lysimachia nummularia L. & KI & $1,3,6,7,8,11,12,15,17$, & sa-CE-M(n) & Primulaceae \\
& & 22,23 & CB & Rosaceae \\
Potentilla anserina L. & KI & 12 & sa-ES-M & Ranunculaceae \\
Ranunculus repens L. & KI & $3,4,5,6,7,8,9,10,11$, &
\end{tabular}

\begin{tabular}{|c|c|c|c|c|}
\hline \multicolumn{5}{|c|}{ Meadows constantly and periodically wet (Order Molinietalia coeruleae W.Koch 1926) } \\
\hline Alopecurus pratensis L. & KI & 22,23 & sa-ES & Poaceae \\
\hline Caltha palustris L. & $\mathrm{KF}$ & $6,21,22$ & $\mathrm{CB}$ & Ranunculaceae \\
\hline Cirsium oleraceum (L.) Scop. & $\mathrm{KI}$ & $\begin{array}{l}4,5,6,7,8,9,10,11,12 \\
13,16,20,22,23\end{array}$ & $\mathrm{ES}(\mathrm{w})$ & Asteraceae \\
\hline Cirsium rivulare (Jacq.) All. & KI & 22,23 & $\mathrm{CE}(\mathrm{s})$ & Asteraceae \\
\hline Crepis paludosa L. Moench & KI & 6 & $\mathrm{CE}$ & Asteraceae \\
\hline Deschampsia caespitosa (L.) P. Beauv. & KA & $5,22,23$ & ES-IR-Asia SE & Poaceae \\
\hline Equisetum palustre L. & KF & $12,20,21,22$ & $\mathrm{CB}$ & Equisetaceae \\
\hline Filipendula ulmaria (L.) Maxim. & $\mathrm{KI}$ & $6,12,20,23$ & sa-ES & Rosaceae \\
\hline Galium uliginosum $\mathrm{L}$. & KI & 21,22 & sa-ES & Rubiaceae \\
\hline Geranium palustre $\mathrm{L}$. & KI & $3,12,20,22,23$ & sa-ES & Geraniaceae \\
\hline Juncus effusus L. & KI & 3,22 & cosmop & Juncaceae \\
\hline Lychnis flos-cuculi L. & KI & 22,23 & sa-ES(w)-M(n) & Caryophyllaceae \\
\hline Mentha longifolia (L.) L. & $\mathrm{KF}$ & $\begin{array}{l}4,5,6,8,11,12,13,20 \\
21,22,23\end{array}$ & $\mathrm{CB}$ & Lamiaceae \\
\hline Mentha spicata L. emend. L. & KI & 12,22 & ES-M & Lamiaceae \\
\hline
\end{tabular}




\begin{tabular}{lcccc}
\hline \multicolumn{1}{c}{ Name of species } & $\begin{array}{c}\text { Category of } \\
\text { spring plants }\end{array}$ & $\begin{array}{c}\text { Number of spring niche } \\
\text { in ONP }\end{array}$ & $\begin{array}{c}\text { Geographical } \\
\text { element }\end{array}$ & Family \\
\hline Myosotis palustris (L.) L. emend. Rchb. & KF & $\begin{array}{l}2,3,5,6,7,11,16,20,21, \\
22,23\end{array}$ & sa-ES-M(n) & Boraginaceae \\
Sanguisorba officinalis L. & KA & 23 & $\begin{array}{c}\text { ES-IR(m)-Asia } \\
\text { E }\end{array}$ & Rosaceae \\
Scirpus sylvaticus L. & KF & $6,12,21,22,23$ & sa-ES(d) & Cyperaceae \\
\hline
\end{tabular}

\begin{tabular}{lllll}
\hline \multicolumn{5}{c}{ Fresh meadows and pastures (Order Arrhenatheretalia Pawł. 1928) } \\
\hline $\begin{array}{l}\text { Alchemilla gracilis Opiz } \\
\text { Arrhenatherum elatius (L.) P. Beauv. Ex J. Presl }\end{array}$ & KA & 3 & CE & Rosaceae \\
$\begin{array}{l}\text { \& C. Presl } \\
\text { Dactylis glomerata L. }\end{array}$ & KA & 23 & sa-CE-M(n) & Poaceae \\
Heracleum sphondylium L. & KA & 23 & sa-ES(d)-M-IR & Poaceae \\
Taraxacum officinale F. H. Wigg. & KA & $4,7,9,10,13,20$ & ES(w) & Apiaceae \\
Trifolium repens L. & KA & 4 & sa-ES-M-IR & Asteraceae \\
Trisetum flavescens (L.) P. Beauv. & KA & 23 & sa-ES-M-IR & Fabaceae \\
\hline
\end{tabular}

\begin{tabular}{|c|c|c|c|c|}
\hline \multicolumn{5}{|c|}{ Fresh and moist meadows (joint species) (Class Molinio-Arrhenatheretea R.Tx. 1937) } \\
\hline Cardamine pratensis $\mathrm{L}$. & KA & 21 & $\mathrm{CB}(\mathrm{w}, \mathrm{n})$ & Brassicaceae \\
\hline Cerastium holosteoides Fr. emend. Hyl. & KA & 23 & sa-ES-M-IR & Caryophyllaceae \\
\hline Festuca pratensis Huds. & KA & 22 & sa-ES-IR(m) & Poaceae \\
\hline Holcus lanatus L. & KA & 23 & sa-CE-M & Poaceae \\
\hline Lathyrus pratensis $\mathrm{L}$. & KA & $12,22,23$ & sa-ES-M-IR & Fabaceae \\
\hline Phleum pratense $\mathrm{L}$. & KA & 22 & sa-ES-M & Poaceae \\
\hline Poa pratensis L. & KA & 22 & CB & Poaceae \\
\hline Poa trivialis $\mathrm{L}$. & KA & 23 & $\begin{array}{c}\text { sa-ES-M(?)- } \\
\text { IR(?) }\end{array}$ & Poaceae \\
\hline Ranunculus acris L. & KA & 23 & sa-ES(w)-M(n) & Ranunculaceae \\
\hline Rumex acetosa $\mathrm{L}$. & KA & $6,7,22,23$ & ES & Polygonaceae \\
\hline \multicolumn{5}{|c|}{ Nitrophilous clippings and ruderal places (Class Epilobietea angustifolii R.Tx. et Prsg 1950) } \\
\hline Fragaria vesca L. & KA & 13 & $\mathrm{CB}$ & Rosaceae \\
\hline Sambucus nigra L. & KA & 4,18 & sa-CE-M & Caprifoliaceae \\
\hline
\end{tabular}

Sambucus nigra $\mathrm{L}$.

Thermophilous thickets (Class Rhamno-Prunetea Rivas Goday et Garb. 1961)

\begin{tabular}{lllll}
\hline Cornus sanguinea L. & KA & 12 & sa-CE-M & Cornaceae \\
Prunus spinosa L. & KA & 4 & sa-CE-M-IR(w) & Rosaceae \\
\hline
\end{tabular}

\begin{tabular}{|c|c|c|c|c|}
\hline \multicolumn{5}{|c|}{ Moist riparian forests (Alliance Alno-Ulmion Br.-B1. et R.Tx. 1943) } \\
\hline Plagiomnium undulatum (Hedw.) T. J. Kop. & KI & $6,7,8,12,13,15,20$ & $\mathrm{CE}$ & Plagiomniaceae \\
\hline Festuca gigantea (L.) Vill. & KA & 6,9 & sa-ES(w)-IR(m) & Poaceae \\
\hline Geranium phaeum L. & KA & $12,15,16,19,23$ & CE: a-ce & Geraniaceae \\
\hline Padus avium Mill. & KI & 18,20 & ES & Rosaceae \\
\hline Stellaria nemorum L. & KA & $1,3,5,19,20$ & CE-M(n) & Caryophyllaceae \\
\hline \multicolumn{5}{|c|}{ Deciduous forests (with different humidity) (Class Querco-Fagetea Br.-Bl. et Vlieg 1937) } \\
\hline Atrichum undulatum Web. et Mohr. & KA & 14,18 & $\mathrm{CB}$ & Polytrichaceae \\
\hline Dryopteris filix-mas (L.) Schott & KA & 18 & $\mathrm{CB}(\mathrm{d})$ & Dryopteridaceae \\
\hline Acer platanoides $\mathrm{L}$. & KA & 13 & $\mathrm{CE}-\mathrm{M}(\mathrm{m})$ & Aceraceae \\
\hline Acer pseudoplatanus L. & KA & $13,17,20$ & $\mathrm{CE}-\mathrm{M}(\mathrm{m})$ & Aceraceae \\
\hline Aegopodium podagraria $\mathrm{L}$. & KA & $\begin{array}{l}1,4,6,7,12,13,14,15 \\
16,19,20,23\end{array}$ & sa-ES(w) & Apiaceae \\
\hline Asarum europaeum L. & KA & 13 & CE-M(n) & Aristolochiaceae \\
\hline Campanula trachelium $\mathrm{L}$. & KA & 13 & sa-ES(w)-M & Campanulaceae \\
\hline Carex sylvatica Huds. & KA & $7,10,13,15,16,17$ & sa-CE-M(n) & Cyperaceae \\
\hline Carpinus betulus L. & KA & 13 & CE-M(n) & Corylaceae \\
\hline Corylus avellana $\mathrm{L}$. & KA & 4 & $\begin{array}{l}\text { sa-CE-M(n)- } \\
\operatorname{IR}(w)\end{array}$ & Corylaceae \\
\hline Epipactis helleborine (L.) Crantz & KA & 13 & sa-ES-M-IR & Orchidaceae \\
\hline Fagus sylvatica L. & KA & 18 & sa-CE(w): ce-b & Fagaceae \\
\hline
\end{tabular}




\begin{tabular}{|c|c|c|c|c|}
\hline Name of species & $\begin{array}{l}\text { Category of } \\
\text { spring plants }\end{array}$ & $\begin{array}{l}\text { Number of spring niche } \\
\text { in ONP }\end{array}$ & $\begin{array}{l}\text { Geographical } \\
\text { element }\end{array}$ & Family \\
\hline Fraxinus excelsior $\mathrm{L}$. & KA & 1,17 & $\begin{array}{l}\text { sa-CE-M(n)- } \\
\text { IR(w) }\end{array}$ & Oleaceae \\
\hline Galeobdolon luteum Huds. & KA & 14 & CE: ece & Lamiaceae \\
\hline Lonicera xylosteum L. & KA & 13 & $\mathrm{ES}(\mathrm{w})$ & Caprifoliaceae \\
\hline Poa nemoralis L. & KA & $2,13,18,19$ & sa-ES-M-IR & Poaceae \\
\hline Primula elatior (L.) Hill. & KA & $14,15,20,23$ & $\mathrm{CE}$ & Primulaceae \\
\hline Pulmonaria obscura Dumort. & KA & $1,13,14,15$ & $\mathrm{CE}$ & Boraginaceae \\
\hline Stellaria holostea L. & KA & 14,15 & sa-ES(w)-M(n, e) & Caryophyllaceae \\
\hline Ulmus glabra Huds. & KA & 17 & sa-CE-M(n) & Ulmaceae \\
\hline Viola reichenbachiana Jord. ex Boreau & $\mathrm{KA}$ & 17 & $\mathrm{CE}(\mathrm{w})-\mathrm{M}(\mathrm{n})$ & Violaceae \\
\hline \multicolumn{5}{|c|}{ Coniferous forests and woods (with different humidity) (Class Vaccinio-Piceetea Br.-B1. 1939) } \\
\hline Pleurozium schreberi (Willd. ex Brid.) Mitt. & KA & 15 & $\mathrm{CB}$ & Hylocomiaceae \\
\hline Oxalis acetosella L. & KA & $13,14,15,17$ & sa-ES & Oxalidaceae \\
\hline \multicolumn{5}{|c|}{ Moist, ruderal and nitrophilous places (Class Artemisietea vulgaris) } \\
\hline Alchemilla glabra Neygenf. & KA & 22,23 & CE: a-ne & Rosaceae \\
\hline Chaerophyllum aromaticum $\mathrm{L}$. & KI & $4,8,10,15,16,18,20,23$ & CE: ece & Apiaceae \\
\hline Epilobium hirsutum $\mathrm{L}$. & $\mathrm{KF}$ & 12 & sa-ES(w)-M-IR & Oenotheraceae \\
\hline $\begin{array}{l}\text { Epilobium parviflorum Schreb. - species } \\
\text { reported in the '60s of the } 20 \text { th century } \\
\text { (Siedlecka-Binder 1967) }\end{array}$ & $\mathrm{KF}$ & 13 & sa-CE-M-IR(w) & Oenotheraceae \\
\hline Epilobium roseum Schreb. & KF & $7,9,11,12,22$ & sa-ES(w) & Oenotheraceae \\
\hline Galium aparine $\mathrm{L}$. & KA & $3,12,20,23$ & $\mathrm{CB}(\mathrm{d})$ & Rubiaceae \\
\hline Geranium robertianum $\mathrm{L}$. & KA & 5 & sa-CE-M-IR & Geraniaceae \\
\hline Geum urbanum $\mathrm{L}$. & KA & $1,4,6,8,14,15,16,17,18$ & $\begin{array}{l}\text { sa-ES(w)-M- } \\
\operatorname{IR}(\mathrm{m})\end{array}$ & Rosaceae \\
\hline Glechoma hederacea L. & KA & 16 & sa-ES-M(n, w) & Lamiaceae \\
\hline Impatiens parviflora $\mathrm{DC}$. & KA & $4,14,15,19,20$ & AT (native) & Balsaminaceae \\
\hline Lamium maculatum $\mathrm{L}$. & KA & 19 & CE-M(n) & Lamiaceae \\
\hline $\begin{array}{l}\text { Petasites hybridus (L.) P. Gaertn., B. Mey. \& } \\
\text { Scherb. }\end{array}$ & KI & 10 & CE-M(n) & Asteraceae \\
\hline Rumex obtusifolius L. & KA & $\begin{array}{l}3,4,6,7,10,11,12,20 \\
22,23\end{array}$ & $\begin{array}{l}\text { sa-CE-M(n)- } \\
\text { IR(w) }\end{array}$ & Polygonaceae \\
\hline Urica dioica $\mathrm{L}$ & KI & $\begin{array}{l}3,4,5,6,7,8,9,10,11,14 \\
19,20,23\end{array}$ & ES-M-IR-Asia E & Urticaceae \\
\hline
\end{tabular}

Weeds of cultivated fields and ruderal places (Class Stellarietea mediae R.Tx., Lohm. et Prsg. 1950)

\begin{tabular}{|c|c|c|c|c|}
\hline Lapsana communis L. & KA & 18 & sa-CE-M(n) & Asteraceae \\
\hline Stellaria media (L.) Vill. & KA & $3,20,23$ & cosmop & Caryophyllaceae \\
\hline Tusilago farfara $\mathrm{L}$. & KA & 3,20 & sa-ES(w)-M(n)-IR & Asteraceae \\
\hline \multicolumn{5}{|c|}{ other habitats (with different humidity) } \\
\hline $\begin{array}{l}\text { Brachytheciastrum velutinum (Hedw.) Ignatov } \\
\text { \& Huttunen }\end{array}$ & $\mathrm{KA}$ & 18 & $\mathrm{CB}$ & Brachytheciaceae \\
\hline Brachythecium rutabulum (Hedw.) Schimp. & $\mathrm{KI}$ & $3,8,14,15,17,20$ & $\mathrm{E}$ & Brachytheciaceae \\
\hline Dichodontium pellucidum (Hedw.) Schimp. & $\mathrm{KF}$ & 20 & $\mathrm{CB}$ & Dicranaceae \\
\hline Didymodon rigidulus Hedw. & KA & 2 & $\mathrm{CB}$ & Pottiaceae \\
\hline Fissidens taxifolius Hedw. & KA & 17 & $\mathrm{E}$ & Fissidentaceae \\
\hline $\begin{array}{l}\text { Fontinalis antipyretica Hedw. - species } \\
\text { reported in the 1960's (Siedlecka-Binder 1967) }\end{array}$ & $\mathrm{KF}$ & 13 & $\mathrm{CB}$ & Fontinalaceae \\
\hline Plagiothecium denticulatum (Hedw.) Schimp. & KI & 18 & $\mathrm{CB}$ & Plagiotheciaceae \\
\hline Aconitum moldavicum Hacq. & KI & 1,15 & $\mathrm{CE}: \mathrm{ct}$ & Ranunculaceae \\
\hline Agrostis capillaris L. & KA & 22,23 & sa-ES-M(n) & Poaceae \\
\hline Ajuga reptans $\mathrm{L}$. & KA & $4,19,20$ & sa-CE-M(n) & Lamiaceae \\
\hline Alchemilla crinita Buser & KA & 23 & CE: a-ce & Rosaceae \\
\hline Chaerophyllum hirsutum L. & $\mathrm{KI}$ & $3,6,7,8,11,12,13,20,23$ & CE: a-ce & Apiaceae \\
\hline Equisetum arvense L. & KA & 20 & CB & Equisetaceae \\
\hline Equisetum sylvaticum L. & $\mathrm{KI}$ & 22 & $\mathrm{CB}$ & Equisetaceae \\
\hline
\end{tabular}




\begin{tabular}{|c|c|c|c|c|}
\hline Name of species & $\begin{array}{l}\text { Category of } \\
\text { spring plants }\end{array}$ & $\begin{array}{l}\text { Number of spring niche } \\
\text { in ONP }\end{array}$ & $\begin{array}{l}\text { Geographical } \\
\text { element }\end{array}$ & Family \\
\hline $\begin{array}{l}\text { Geum rivale L. - species reported earlier by } \\
\text { Sołtys (2005) }\end{array}$ & $\mathrm{KI}$ & 6 & $\mathrm{CB}(\mathrm{d})$ & Rosaceae \\
\hline Hedera helix $\mathrm{L}$. & KA & 1 & sa-CE(w)-M & Araliaceae \\
\hline Lolium perenne L. & KA & 4 & sa-CE-M-IR(w) & Poaceae \\
\hline $\begin{array}{l}\text { Mentha aqatica L. - species reported in the } \\
\text { 1960s (Siedlecka-Binder 1967) }\end{array}$ & $\mathrm{KF}$ & 13 & sa-ES(w)-M & Lamiaceae \\
\hline Mycelis muralis (L.) Dumort. & KA & 13 & $\mathrm{CE}$ & Asteraceae \\
\hline Pimpinella saxifraga $\mathrm{L}$. & KA & 23 & sa-ES(w)-M(n) & Apiaceae \\
\hline Poa anпua $\mathrm{L}$. & KA & 9 & $\begin{array}{l}\text { sa-ES-M-IR-Asia } \\
\text { E }\end{array}$ & Poaceae \\
\hline Veronica chamaedrys L. & KA & $3,6,7,10,11$ & sa-ES-M(n) & Scrophulariaceae \\
\hline
\end{tabular}

Explanations: category of spring plants, $\mathrm{KO}$ - obligatory krenophytes, $\mathrm{KF}$ - facultative krenophytes, $\mathrm{KI}$ - indifferent krenophytes, KA-accidental krenophytes; geographical element (according Hill et al. 2007 and Zając \& Zając 2009), AT - Asian Temperate (native range), CB - Circum-Boreal sub-element, CB: c-b-o - Circum-Boreal-Oceanic group, CB: c-b-a - Circum-Boreal-Arctic group, E - European element, ES - Euro-Siberian sub-element, CE - European-temperate sub-element, CE: ece - East-European distributional type, CE: ce-b - European-temperate Balkan distributional type, CE: a-ce - Alpine-Central-European distributional type, CE: a-ne - Alpine-North-European distributional type, CE: ct - Carpathian distributional type, H - Holarctic element, IR - Irano-Turanian element, M - Mediterranean element, PAN-PONT - Pontic-Pannonian sub-element, cosmop - Cosmopolitan element; additional designations, $\mathrm{d}$ - disjunctive range, $\mathrm{e}$ - eastern, $\mathrm{m}$ - in a mountain regions, $\mathrm{n}$ - northern, $\mathrm{s}$ - southern, $\mathrm{sa}$ - extension in the beginning of diagnosis to the Atlantic region of Europe, $\mathrm{w}-$ western, ? - doubtful to a diagnosis of the part of element 